IZA DP No. 8766

The Effects of Increasing the Standards of the High School Curriculum on School Dropout

Katja Görlitz

Christina Gravert

January 2015 


\title{
The Effects of Increasing the Standards of the High School Curriculum on School Dropout
}

\author{
Katja Görlitz \\ FU Berlin, IZA and RWI Essen \\ Christina Gravert \\ University of Gothenburg
}
Discussion Paper No. 8766
January 2015

\author{
IZA \\ P.O. Box 7240 \\ 53072 Bonn \\ Germany \\ Phone: +49-228-3894-0 \\ Fax: +49-228-3894-180 \\ E-mail: iza@iza.org
}

\begin{abstract}
Any opinions expressed here are those of the author(s) and not those of IZA. Research published in this series may include views on policy, but the institute itself takes no institutional policy positions. The IZA research network is committed to the IZA Guiding Principles of Research Integrity.

The Institute for the Study of Labor (IZA) in Bonn is a local and virtual international research center and a place of communication between science, politics and business. IZA is an independent nonprofit organization supported by Deutsche Post Foundation. The center is associated with the University of Bonn and offers a stimulating research environment through its international network, workshops and conferences, data service, project support, research visits and doctoral program. IZA engages in (i) original and internationally competitive research in all fields of labor economics, (ii) development of policy concepts, and (iii) dissemination of research results and concepts to the interested public.
\end{abstract}

IZA Discussion Papers often represent preliminary work and are circulated to encourage discussion. Citation of such a paper should account for its provisional character. A revised version may be available directly from the author. 


\section{ABSTRACT}

\section{The Effects of Increasing the Standards of the High School Curriculum on School Dropout ${ }^{*}$}

This paper evaluates the effects of a high school curriculum reform that was introduced in one German state on high school dropout. The reform increased the standards of the curriculum by reducing the freedom of choice in course selection (amongst other things) resulting in an increase in the level and the weekly teaching hours in the subjects German, a foreign language, mathematics and natural sciences. Using a quasi-experimental evaluation design exploiting variation across time and states, we identify the reform effect on students' probability to graduate from high school. The results show that high school dropout rates have increased for males and females alike. However, the effect for males vanishes two years after reform implementation, while it remains persistent for females even after three years.

JEL Classification: D04, 121, 128

Keywords: high school curriculum reform, high school dropout, school performance

Corresponding author:

Katja Görlitz

Freie Universität Berlin

Boltzmannstraße 20

14195 Berlin

Germany

E-mail: katja.goerlitz@fu-berlin.de

\footnotetext{
* The authors are grateful to Alexander Koch, Helena Skyt Nielsen and Marcus Tamm for helpful comments and suggestions. We also thank Silva Haselon for research assistance. Furthermore, we acknowledge comments and remarks from participants at the annual conference of the Royal Economic Society (2013), the Research Seminar in Economics at the FU Berlin, the DIW Applied Micro seminar, the Economics of Education Committee of the Verein für Socialpolitik (2014) and the Fuglesangs Alle Workshop (2014). All remaining errors are our own.
} 


\section{Introduction}

One essential aim of primary and secondary schooling is to equip students with the basic skills necessary to successfully enter the labor market or to pursue a postsecondary education. Nevertheless, international standardized achievement tests show that many students in the US and in Europe are lacking these skills (Hanushek and Woessmann 2011). While the reasons for this lack are manifold, the school curriculum has become a central topic of the political agenda in many countries in the last decade. In the US and the EU, reforms of the curriculum that were targeted at increasing students' competencies in core skills such as mathematics, reading and writing have already been carried out (as in Germany) or are envisioned. ${ }^{1}$ Focusing on the high school curriculum has much appeal given the policy makers' duty and freedom to design its organization and content.

These curricula reforms have in common that they increase the degree of difficulty to graduate from high school. Higher curriculum standards might well improve students' skills but they could come at the cost of increasing students' dropout rates. This paper arguably presents the best evidence to date on the causal effects of increasing the high school curriculum standard on high school dropout. The analysis is based on administrative data covering the multitude of high school students. Using a differencein-differences approach, the effects are identified by comparing the developments of high school dropouts between the German state Baden-Württemberg (that has introduced a curriculum reform) and the other German states in the pre- and post-reform period. The curriculum of the last two years of high school was changed significantly. One of the core elements of the reform was to reduce students' freedom to choose subjects on an advanced or basic level. After reducing this freedom of choice, the average student experienced a significant increase in the level and the intensity (in terms of weekly hours) in the core subjects German, a foreign language, mathematics and natural sciences.

We are only aware of one study analyzing the hypothesis that more stringent high school requirements could boost high school dropout rates. Harvill (2011) models the education and dropout decision theoretically and estimates the parameters using prereform data of an American high school graduation requirement reform. Her simulation results predict a large increase in school dropouts. In contrast to her results, our paper contributes to the literature by presenting ex-post evaluation results of a curriculum reform. Besides this small strand of literature focusing on high school dropout, there is a small but growing literature concerned with the effects of the high school curriculum on university entry (Aughinbaugh 2012), university graduation rates and labor market success (e.g. Altonji 1995, Levine and Zimmerman 1995, Dolton and Vignoles 2002, Rose and Betts 2004, Joensen and Nielsen 2009, Goodman 2012). However, a comprehensive analysis of the curriculum effects on further education outcomes also

\footnotetext{
${ }^{1}$ Some examples of curriculum reform initiatives include: "Make university a reality" or "Achieve” for the US and the Europe 2020 strategy for the EU.
} 
requires investigating potential effects on the high school graduation probability. An understanding of possible selection effects through high school dropout is important for describing the channels through which a curriculum reform affects outcomes later in life.

This paper also contributes to the literature by exploring reform avoidance effects. We answer the question whether students avoid the reform by switching to schools that are unaffected by the reform. This was possible in Baden-Württemberg as the curriculum reform that is in the focus of this paper was introduced for the graduation cohort of 2004 in academic high schools only. Vocational high schools, in contrast, introduced a similar but less demanding curriculum reform starting with the graduation cohort of 2005. Therefore, students graduating in 2004 had a particularly high incentive to avoid the reform by switching to another school, but the avoidance possibilities also remained afterwards because of the overall lower curriculum standards in vocational high schools.

The final contribution of this paper is to present indicative evidence on the question whether a potential increase in high school dropout is caused by students not passing the final high school exam, e.g., because of the increase in the curriculum standards, or by students who left the high school by choice, e.g., because of having doubts to cope with the increased requirements. The latter case is possible in Germany as a significant share of high school graduates do not pursue a university education anyway, but chose to participate in the apprenticeship training system that is also open for high school dropouts.

The paper proceeds as follows. Section 2 describes the German schooling system with a particular focus on Baden-Württemberg and the curriculum reform in more detail. The data and the empirical methods are introduced in section 3. Section 4 presents the results for high school dropout. Section 5 sheds some light on students' probability to pass the final exam or to leave the high school by choice. The final section concludes the study.

\section{Institutional background and the reform}

\subsection{The high school system}

The German education policy is set on the level of the 16 federal states. The German schooling system is characterized by early tracking usually after the fourth or sixth grade, i.e. when pupils are at the age of ten or twelve, respectively. The choice of school track is based on individuals' ability and school achievement. The top-level school track is the high school (Gymnasium) which usually requires 13 years of schooling to obtain a high school degree (Abitur). ${ }^{2}$ Two different types of high schools can be distinguished: academic high schools (preparing students for university studies in general) and

\footnotetext{
${ }^{2}$ There were two East German states (Saxony and Thuringia) where high school duration required traditionally only 12 years of schooling.
} 
vocational high schools (imparting more vocationally oriented knowledge). Even though vocational high schools only play a minor role in Germany (where only one out of ten high school graduates comes from vocational schools), they have a strong tradition in Baden-Württemberg (where approximately one third of all graduates come from vocational schools). However, as the vast majority of all German top-level school track students attends the academic high school and as the curriculum reform that is in the focus of this analysis was introduced in academic high schools, the following descriptions refer to academic high schools in the pre-reform period (if not indicated otherwise).

The curriculum of the academic high school usually differs by grade in Germany. Until grade 11, every student has the same fixed curriculum and is taught within a class having the same peers each grade. ${ }^{3}$ In the last two years of high school (usually in grade 12 and 13), the classes are dissolved and each student decides on his own set of courses. Students choose two advanced and several basic courses from a variety of subjects. Some subjects can even be dropped. Although some restrictions in course selection exist, students have a great deal of freedom of choice to specialize in particular subjects. For example, while some students choose arts and French as their advanced subjects (dropping physics and chemistry), others specialize in mathematics and physics on the advanced level (dropping arts and French). In vocational high schools the structure is similar, but slightly less flexible due to their vocational focus (e.g. on business studies and economics, social sciences, technology or natural sciences).

To acquire a high school diploma, three written high school exams and one oral exam have to be passed in the two advanced subjects and in two basic subjects at the end of 13th grade. Some limitations exist when deciding upon which basic subject is examined in the final exams. For instance, before the reform students in Baden-Württemberg were required to pass the final exam in German and mathematics at least at the basic level. The high school grade that is equivalent to the grade point average (GPA) is calculated out of the grades obtained in the final high school exams in addition to all grades obtained in all subjects in the last two years of high school.

\subsection{The curriculum reform}

In the end of 1999, Baden-Württemberg decided to introduce a curriculum reform limiting the freedom of choice in course selection during the last two years of academic high school. The first cohort affected by the reform entered grade 12 in 2002 and graduated from high school in 2004. The aim of the reform was to increase broader general knowledge in the three core subjects German, a foreign language and mathematics. These subjects were made mandatory on an advanced level for all students. In addition, students' could choose two further subjects on an advanced level -

\footnotetext{
${ }^{3}$ In Saxony and Thuringia, this is the case until grade 10.
} 
either another foreign language and/or a natural science. ${ }^{4}$ Before the reform, the two advanced subjects were taught for five hours a week. After the reform, the amount of hours was reduced to four hours for each advanced subject.

Another aim of the reform was to strengthen natural sciences. Hence, the curriculum was also changed with respect to these subjects. Before the reform, students interested in natural sciences could only choose one natural sciences on the advanced level, while they could choose two after the reform. The number of mandatory natural sciences subjects also increased for those students who were less interested in natural sciences from one (before the reform) to two afterwards.

These changes rose the total instruction time at school from a minimum of weekly 26 hours to a minimum of 30 hours per week. The number of final exams increased from four to six. All three core subjects and another advanced subject were part of the final written exams. The fifth and sixth components were oral exams, one of them in either the fifth advanced subject or one of the basic subjects and the other one in one of the written exam subjects. Besides these changes in the course choice system and in the instruction time, the curriculum of the advanced subjects changed as well. The level and intensity of the main topics stayed the same as in the pre-reform advanced subjects, but the number of specialized topics decreased to accommodate the reduction in weekly hours. Table 1 summarizes the main changes of the curriculum.

Since before the reform, most students selected the core subjects on a basic level rather than on an advanced level, the level and instruction time in the core subjects increased for the average high school student. The average weekly hours in German increased by more than 15 percent (Neumann 2010), in English as a foreign language by 6 percent (Jonkmann et al. 2010) and in mathematics by 7 percent (Nagy et al. 2010). In natural sciences, the average weekly hours increased the most by 30 percent (Neumann and Nagy 2010). While only one fifth of students chose science as an advanced course before the reform, more than half chose a natural science on the advanced level after the reform.

The reform has already been evaluated with regard to its potential to increase school achievement based on data that was particularly designed for this purpose. Students' achievement was measured with tests similar to the PISA tests (Programme for International Student Assessment). Nagy et al. (2010) show that the reform increased achievement scores in mathematics. In contrast, Jonkmann et al. (2010) and Neumann and Nagy (2010) find no significant achievement effects in English as a foreign language or in natural sciences, respectively. These findings are in line with the literature concerned with the effects of instruction time on achievement scores that find the instruction time to matter more for achievement in mathematics compared to other subjects like languages (Lee and Barro 2001, Woessmann 2003, Marcotte 2007).

\footnotetext{
${ }^{4}$ For some students it was also possible to select art, music or sports as an advanced subject.
} 
The curriculum reform in the way it was described above was only implemented in academic high schools. In vocational high schools, the reform was introduced one year later and in a modified version that did not increase the degree of difficulty to such a large extent. German, mathematics and a foreign language also became mandatory on an advanced level, but students had to take only one further advanced course which could have a vocational focus (e.g. agricultural science, biotechnology, nutrition science, social pedagogy, economics or technology). Instead of the mandatory two natural sciences courses, students could still graduate with just one natural science. Moreover, students faced one final exam less and under certain circumstances they could even replace two more exams with a written report or a project.

\section{Data and empirical strategy}

\subsection{Data}

The data set used was constructed by combining two administrative sources. The first data set contains the number of all graduates from academic or vocational high school by state and year of high school graduation that is provided by the Federal Statistical Office (Statistisches Bundesamt 2005 and 2008, GENESIS-online Datenbank). The second data set contains annual information on the size of the age-specific cohort (Statistisches Bundesamt 2005 and 2008), in particular, the number of individuals that are of the same age as high school students during their graduation (age 19). Both sources are available separately by gender. Out of these two data sets, a repeated crosssectional micro data is constructed for the time period 1999 to 2006 that contains one observation for every individual of age 19 by year and state showing whether this individual has graduated from academic, vocational or no high school. Henceforth, this data set is referred to as the "Register of high school graduates combined with data on the age-specific cohort”.

Descriptive statistics of the variables of interest are contained in Table 2. The share of males graduating from academic high school is 20 percent and it is 4 percent for graduation from vocational high school. For females, the corresponding shares are 27 percent for academic high school and 5 percent for vocational high school. The developments of the share of students graduating from academic high school over time and by treatment and control states are contained in Figure $1 .{ }^{5}$ Both males' and females' development in Baden-Württemberg converge to the development of the control states in the pre-reform. In the post-reform period (especially in 2004), the shares decline for both males and females alike. With regard to the share of graduates from vocational high school (Figure 2), the development in the pre-reform period looks more similar between treatment and control states. However, based on the visual inspection it is hard to draw conclusions about the existence of a time trend which is why it is tested in the applied empirical model.

\footnotetext{
${ }^{5}$ Section 3.2 presents and discusses the definition of the control group.
} 


\subsection{Estimation strategy}

The effects of the curriculum reform on individuals' probability to graduate from high school are evaluated by applying the difference-in-differences approach. The development of the outcome variables of interest in the pre- and post-period of the treatment state Baden-Württemberg is compared to the corresponding development of the control states. The control group is composed of all the other German states excluding Hesse, Mecklenburg-Western Pomerania and Saxony-Anhalt because they have implemented school reforms in the time period under investigation (e.g. increasing the years of high school from initially 12 to 13 years). This leaves 12 states in the control group. The following main specification is estimated separately by gender:

$Y_{i s t}=\alpha_{s}+\gamma_{t}+\beta_{03} D_{1 s t}+\beta_{04} D_{2 s t}+\beta_{05} D_{3 s t}+\beta_{06} D_{4 s t}+\delta T+\varepsilon_{i s t}$

where $Y$ indicate the binary outcome variables displaying the probability to graduate (i) from academic high school and (ii) from vocational high school of individual $i$ in the state $s$ and year $t$ of high school graduation (with $t=99,00,01,02,03,04,05,06$ ). $\alpha$ is a state fixed effects and $\gamma$ is a year fixed effects. $\varepsilon_{i s t}$ is an idiosyncratic error term. The empirical specification was chosen to investigate the reform effects separately for every of the post-reform graduation years 2004 to 2006 and for the pre-reform graduation year 2003 to test for anticipation effects. The anticipation effects reveal whether students have reacted to the reform prior to its implementation, e.g. by increasing their efforts to graduate in 2003 instead of 2004. They are indicated by $\widehat{\beta}_{03}$ and estimated by the dummy variable $\mathrm{D}_{1}$ that represents the interaction between Baden-Württemberg and the year 2003.

$D_{2}$ represents a dummy variable being 1 in the first post-reform year 2004 in BadenWürttemberg, and 0 otherwise. As already mentioned in the second section, this is of particular importance because the reform was only implemented in academic high schools for students who graduated in 2004 and in vocational high school for students graduating in 2005. This left students from the graduation cohort 2004 the opportunity to change schools in order to avoid the reform. It should be noted that the effects in 2004 might also differ for other reasons. In the first year of the new curriculum, students' and teachers' insecurity is larger compared to other years which in turn might affect dropouts. The coefficient $\hat{\beta}_{04}$ tests for different effects in 2004.

The dummy variables $D_{3}$ and $D_{4}$ are the interaction terms of the treatment state BadenWürttemberg with the post-reform graduation years 2005 and 2006, respectively. Thus, the "clean" reform effects (adjusted for potential school changes) are indicated by $\hat{\beta}_{05}$ and $\hat{\beta}_{06}$. The variable $T$ is the interaction between a linear time trend and the state Baden-Württemberg in order to control for time trends in the pre-reform period 1999 to 2002. Based on the visual inspection of Figure 1, we have hypothesized that differential time trends between treatment and control states matter in the pre-reform period. 
Equation (1) allows us to test this hypothesis empirically by estimating the coefficient $\delta$. To check the robustness of specification (1) that considers a time trend, we also estimate the following equation (also separately by gender):

$Y_{i s t}=\alpha_{s}+\gamma_{t}+\beta_{03} D_{1 s t}+\beta_{04} D_{2 s t}+\beta_{05} D_{3 s t}+\beta_{06} D_{4 s t}+I^{\prime} \eta+v_{i s t}$

which only differs compared to equation (1) by not considering $\delta T$. Instead the vector $I$ is included that contains three interaction effects between Baden-Württemberg and each of the years 1999, 2000 and 2001. The year 2002 serves as the reference year. In other words, equation (1) assumes that any patterns of convergence observable before the reform would have continued after the reform, if the reform has not been implemented. In contrary, equation (2) assumes that the time trend would have ended after 2002. The error term is indicated by $v_{i s t}$.

Equation (1) and (2) are estimated by the linear probability model. One issue that was much debated in the literature when using difference-in-differences models is the correct estimation of standard errors (see e.g. Moulton, 1990 or Bertrand et al., 2004). Calculation of standard errors without any correction leads to downward biased standard errors. To take this issue into account, standard errors are clustered at the stateyear level when estimating equation (1) and (2). To prove that this procedure is robust, alternative calculations of the standard errors that are frequently used in the literature are presented and compared to our main results in the sensitivity analysis.

One obvious shortcoming with our data is that they do not allow us to consider any individual control variables in the regression framework. This would bias our results, if students' characteristics like their socio-economic background have changed during the time period under investigation. One counter argument is that we consider a rather short time period that makes changes in "quasi" time-invariant variables more unlikely (like parents' educational or occupational level). Additionally, section 4.2 presents evidence from the literature showing that the average characteristics of the students in BadenWürttemberg have not changed between the pre- and post-reform period.

\section{Results}

\subsection{Main Results}

Table 3, Panel A presents the results for the individuals' probability to graduate from academic high school separately by gender. For males, the main specification with a time trend and the specification without a time trend provide a statistically significant negative reform effect on graduating from academic high school in Baden-Württemberg in 2004 and 2005 (see column 1 and 2). However, the size of the effect is much larger in the specification considering a time trend where the reform effect is -2 percentage points in 2004 and -1.8 percentage points in 2005. When using the specification with not time trend, the effects are -1.5 percentage points in 2004 and -1 percentage point 
in 2005. For females, there is also a statistically significant negative effect in 2004 and 2005, but also in 2006 which contrasts to the results for males. In the specification with trend (column 3), females' likelihood to graduate from academic high school decreases by 3.1 percentage points in 2004, by 2.6 percentage points in 2005 and by 3 percentage points in 2006. The results without considering a time trend (column 4) are of similar sign and significance which indicates that females' probability to graduate from academic high school decreased by 2 percentage points in 2004 and by approximately 1 percentage point in each 2005 and 2006.

Table 3, Panel B contains the results concerning the probability to graduate from vocational high school. Males' probability increased in 2003, 2004 and 2005. In the specification with trend (column 1), the effects are modest in size with 0.3 percentage points in 2003 and 0.6 percentage points in both 2004 and 2005. The same is true for the effects in the specification without trend (column 2) where they are 0.2 percentage points in 2003, 0.4 in 2004 and 0.3 in 2005. For females, it should be noted that the results differ substantially by the specifications used (column 3 and 4). Because the time trend cannot be confirmed to be statistically significant, the specification without time trend is the adequate one. The results indicate a statistically significant positive effect in all years with a size ranging between 0.2 and 0.4 percentage points.

In sum, there is evidence of a reduced probability of graduating from academic high school in 2004 for male and female students. In 2005, the effects are also negative for both genders, but they are of smaller size. While for males, the negative effect vanishes in 2006, it remains negative for females. At the same time, the probability to graduate from vocational high school has increased for both males and females. This result indicates that some students have used the possibility to change schools to avoid the reform in academic high school (especially in 2004). However, it should be noted that in terms of its size the increase in the probability to graduate from vocational high school cannot fully account for the decrease in the probability to graduate from academic high school. Therefore, the probability to graduate from any high school, i.e. either academic or vocational, has decreased. This is also confirmed when running the difference-in-differences regressions using any high school as dependent variable (results not shown).

\subsection{Sensitivity analysis}

To check the robustness of our results, we run a variety of sensitivity checks. Table 4 documents the results of applying alternative calculations of the standard errors. Clustering on the state level and on the state-pre/post level (that allows for temporal breaks in the dependence of the error term over time) to account for a serial correlation does not change the results (column 2, 3, 6 and 7). The method suggested by Bester et al. (2011) allows for dependence over states and time. We implement this method by defining five geographically areas (in particular, Northwest, East, West, Southwest and Southeast). Inference is based on a t-distribution with four degrees of freedom. These 
standard errors are also consistent with those of our main specification (column 4 and 8).

To find out whether our results were actually caused by other shocks that could have occurred in any of the other control states, we have run the main specification excluding one state at a time from the control states. ${ }^{6}$ Table 5 summarizes the main results for males and Table 6 for females. The main conclusion remains unchanged by this sensitivity checks. As another robustness check, we have excluded Saxony and Thuringia from the set of control states because they only require 12 years of high school. This did not alter our main conclusions (results not shown).

The data set does not allow us to consider any control variables. This could bias our results, if the socio-economic background or school performance of high school students has changed in Baden-Württemberg before and after the reform. Becker et al. (2010) shows empirically that the average characteristics of students (including parents' education and occupation, migration background and having more than 100 books at home) remained stable between 2002 and 2006. Their analysis is based on the data that was particularly designed to evaluate whether the curriculum reform in BadenWürttemberg had an impact on students' school achievement (TOSCA-2002 and TOSCA-2006). To illustrate how little the characteristics have changed over time, Table 7 summarizes the means of students' characteristics in 2002 and 2006 from Becker et al. (2010).

\section{Discussion}

The negative impact of the reform on students' likelihood to graduate from academic high school could be caused involuntarily by students who did not pass the exam (because of the higher curriculum standard) or it could be due to students who left high school by choice (e.g. because of having doubts to cope with the higher standard). The latter case is likely in Germany as leaving school after having successfully completed grade 10 of the academic high school leads to a secondary school diploma that is equivalent to the level 3C of the International Standard Classification of Education (ISCED). This school diploma qualifies students for participation in the dual apprenticeship system that offers good employment and wage prospects in many occupations. $^{7}$

To distinguish between the two possibilities, we analyze data on students' probability to pass the final high school exam and conditional on passing on high school grades (that have a range from 1 which is the best grade to 4 which is the worst). If these variables were negatively affected by the reform, i.e. if the probability to pass the exam and of high school grades decreased, we conclude that high school dropout was caused by involuntary high school dropout. In the absence of negative effects, we conclude that

\footnotetext{
${ }^{6}$ See Hübner (2012) for another application of this sensitivity check.

${ }^{7}$ See e.g. Steedman (1993) for a more detailed description of the German apprenticeship system.
} 
the reform changed students' high school choices. The analysis is based on administrative data on high school exams that is collected and provided by the KMK for the time period 2002 to 2005 for most of the German states (Sekretariat der Ständigen Konferenz der Kultusminister der Länder in der Bundesrepublik Deutschland 2004 to 2007). The data only covers information from academic high schools (and not from vocational high schools) ${ }^{8}$ and they are not separately provided by gender. As the data was not collected before 2002, we can neither provide evidence on the common trend assumption, nor can we incorporate time trends in the regression. Due to these reasons, we interpret our results as indicative evidence rather than as robust causal effects.

The estimated regression model is closely linked to equation (2) which is the empirical specification with no time trends incorporated:

$Y_{i s t}=\alpha_{s}+\gamma_{t}+\beta_{03} D_{1 s t}+\beta_{04} D_{2 s t}+\beta_{05} D_{3 s t}+u_{i s t}$.

$Y$ indicates the outcome variables (i) for passing the high school exam and (ii) for the high school grades (restricted to individuals having successfully passed the exam) for individual $i$ in state $s$ in year $t$ of high school graduation. $D_{1}\left(D_{2}, D_{3}\right)$ represents a dummy variable that is 1 in the year $2003(2004,2005)$ in Baden-Württemberg, and 0 otherwise. As before, $\alpha$ are state and $\gamma$ year fixed effects. $u_{i s t}$ is an idiosyncratic error term. In the main specification, inference is based on clustering at the state-year level. For reasons of robustness, state clusters and five region clusters are applied as well. Clustering at the state and pre/post level is equivalent to using state year clusters as the pre-period only consists of one year (2005).

Panel A of Table 8 illustrates the results for the students' probability to pass the high school exam. In all specifications (column 1 to 3), there are statistically significantly positive effects in 2004 and 2005. A positive effect reinforces the hypothesis that the reform has induced students to leave high schools by choice. If the weakest students with the lowest probability to pass have decided to leave the high school, the remaining students are a positively selected group that could have a higher probability of passing. This could be the reason why there are even positive effects in the two post-reform years. In one specification, there is a statistically significant effect in 2003 which is not a robust finding as the results for 2004 and 2005 are. Panel B of Table 8 displays the results when analyzing the average grade of high school graduates indicating no effects in any specification and year (with one minor exception).

To further interpret this result, it seems appropriate to combine these findings with the evidence provided in Görlitz and Gravert (2014) who analyze empirically the question whether the reform has affected individuals' likelihood to enroll at university. The empirical results indicate that the enrollment probability did not decrease; in fact, it

\footnotetext{
8 Since 2006, the high school grades refer to grades in academic and vocational high schools. Therefore, the information is no longer comparable with the previous years and cannot be analyzed within a difference-in-differences framework.
} 
even increased for males and females. Therefore, we conclude that it is those students who chose to drop out of school by choice that would not need a high school degree anyway for their further education (for instance, within the apprenticeship training system).

\section{Conclusion}

This paper analyzes the effects of a curriculum reform on the students' probability to graduate from high school. The reform increased the level of difficulty for obtaining an academic high school degree, for instance, by reducing the freedom of choice in course selection which increased the mandatory instruction hours in German, a foreign language, math and natural sciences for the average student. Since the reform was only implemented in one state, we apply a difference-in-differences approach to identify the reform effects. The analysis is based on administrative data covering the universe of high school graduates that was combined with information on the age-specific cohort.

The results show that the curriculum reform reduced students' probability to graduate from academic high schools. Even though many of the results are similar between males and females, it should be mentioned that the negative impact on academic high school vanishes in 2006 for males, while it remains significantly negative for the whole postreform period for females. Further evidence suggests that the negative effect on academic high school is caused by students' choices to leave school rather than by not passing the final exam. The gender difference in the results could be explained by the suggestion that girls try more strongly to avoid the mandatory course load in math and sciences after the reform (even in the longer run) by choosing not to go (any longer) to high school. This would be in line with the well-documented fact that girls more often report about mathematics anxiety. Their beliefs about their mathematical competences are also lower than that of boys even after controlling for achievement scores in math (Else-Quest et al. 2010, Pope and Sydnor 2010, Goetz et al. 2013).

For males and females alike, the most pronounced negative effect can be found in the year 2004 right after the reform was implemented. The results indicate that some students from the graduation cohort 2004 used the possibility to switch from academic to vocational high school to avoid the reform. From this result, we derive the policy recommendation that policy makers should leave as little options as possible for students to avoid reforms. In addition, researchers who intend to evaluate education reforms should adjust their estimation strategy to control for the likely occurrence of selective school changes.

\section{References}

Altonji, J. G. (1995), The Effects of High School Curriculum on Education and Labor Market Outcomes. The Journal of Human Resources, 30 (3), 409-438. 
Aughinbaugh, A. (2012), The effects of high school math curriculum on university attendance: Evidence from the NLSY97. Economics of Education Review, 31, 861-870.

Becker, M., K. Maaz and M. Neumann (2010), Schulbiografien, familiärer Hintergrund und kognitive Eingangsvoraussetzungen im Kohortenvergleich. 127-146. In: Trautwein, U., M. Neumann, G. Nagy, O. Lüdtke and K. Maaz (eds.), Schulleistungen von Abiturienten. Die neu geordnete gymnasiale Oberstufe auf dem Prüfstand. VS Verlag, Wiesbaden.

Bertrand, M., E. Duflo, and S. Mullainathan (2004), How Much Should We Trust Differences-in-Differences Estimates? The Quarterly Journal of Economics, 119 (1), 249-275.

Bester, C. A., T. G. Conley and C. B. Hansen (2011), Inference with dependent data using cluster covariance estimators. Journal of Econometrics, 165 (2), 137-151.

Dolton, P. J. and A. Vignoles (2002), Is a broader curriculum better? Economics of Education Review, 21, 415-429.

Donald, S. G. and K. Lang (2007), Inference with Difference-in-Differences and Other Panel Data. The Review of Economics and Statistics, 89 (2), 221-233.

Else-Quest, N. M., J. S. Hyde and M. C. Linn (2010), Cross-national patterns of gender differences in mathematics: A meta-analysis. Psychological Bulletin, 136 (1), 103-127.

Ganzeboom, H. B. G., P. M. DeGraaf, D. J. Treiman and J. DeLeeuw (1992), A standard international socioeconomic index of occupational status. Social Science Research, 2, 1-56.

Goetz, T., M. Bieg, O. Lüdtke, R. Pekrun and N. C. Hall (2013), Do Girls Really Experience More Anxiety in Mathematics? Psychological Science, 24 (10), 2079-2087.

Görlitz, K. and C. Gravert (2014), The effects of a high school curriculum reform on university enrollment and the choice of college major. Mimeo.

Goodman, J. (2012), The labor of division: Returns to compulsory math coursework. HKS Faculty Research Working Paper RWP12-32.

Hanushek, E. A. and L. Woessmann (2011), The Economics of International Differences in Educational Achievement, 89-200. In: Hanushek, E. A., S. Machin and L. Woessmann (eds.), Handbook of the Economics of Education, VOL 3, North Holland, Amsterdam.

Harvill, E. L. (2011), High School Math Curriculum, Student's Course Selection and Education Outcomes. Publicly accessible Penn Dissertations, Paper 363. 
Hübner, M. (2012), Do tuition fees affect enrollment behavior? Evidence from a 'natural experiment' in Germany. Economics of Education Review, 31 (6), 949-960.

Joensen, J. S. and H. S. Nielsen (2009), Is there a Causal Effect of High School Math on Labor Market Outcomes? The Journal of Human Resources, 44, 171-198.

Jonkmann, K., U. Trautwein, G. Nagy and O. Köller (2010), Fremdsprachenkenntnisse in Englisch vor und nach der Neuordnung der gymnasialen Oberstufe in BadenWürttemberg. 181-214. In: Trautwein, U., M. Neumann, G. Nagy, O. Lüdtke and K. Maaz (eds.), Schulleistungen von Abiturienten. Die neu geordnete gymnasiale Oberstufe auf dem Prüfstand. VS Verlag, Wiesbaden.

Lee, J.-W. and R. J. Barro (2001), School Quality in a Cross-Section of Countries. Economica, 68, 465-488.

Levine, P. B. and D. J. Zimmerman (1995), The Benefit of Additional High School Math and Science Classes for Young Men and Women. Journal of Business and Economic Statistics, 13 (2), 137-149.

Marcotte, D. E. (2007), Schooling and Test Scores: A Mother-Natural Experiment. Economics of Education Review, 26 (5), 629-640.

Moulton, B. R. (1990), An Illustration of a Pitfall in Estimating the Effects of Aggregate Variables on Micro Units. The Review of Economics and Statistics, 72 (2), 334-338.

Nagy, G., M. Neumann, U. Trautwein and O. Lüdtke (2010), Voruniversitäre Mathematikleistungen vor und nach der Neuordnung der gymnasialen Oberstufe in Baden-Württemberg. 147-180. In: Trautwein, U., M. Neumann, G. Nagy, O. Lüdtke and K. Maaz (eds.), Schulleistungen von Abiturienten. Die neu geordnete gymnasiale Oberstufe auf dem Prüfstand. VS Verlag, Wiesbaden.

Neumann, M. (2010), Innovation oder Restauration- Die (Rück-?)Reform der gymnasialen Oberstufe in Baden-Württemberg. 37-90. In: Trautwein, U., M. Neumann, G. Nagy, O. Lüdtke and K. Maaz (eds.), Schulleistungen von Abiturienten. Die neu geordnete gymnasiale Oberstufe auf dem Prüfstand. VS Verlag, Wiesbaden.

Neumann, M. and G. Nagy (2010), Mathematische und naturwissenschaftliche Grundbildung vor und nach der Neuordnung der gymnasialen Oberstufe in BadenWürttemberg. 215-242. In: Trautwein, U., M. Neumann, G. Nagy, O. Lüdtke and K. Maaz (eds.), Schulleistungen von Abiturienten. Die neu geordnete gymnasiale Oberstufe auf dem Prüfstand. VS Verlag, Wiesbaden. 
Pope, D. G. and J. R. Sydnor (2010), Geographic Variation in the Gender Differences in Test Scores. Journal of Economic Perspectives, 24 (2): 95-108.

Rose, H. and J. R. Betts (2004), The Effect of High School Courses on Earnings. The Review of Economics and Statistics, 86 (2), 497-513.

Sekretariat der Ständigen Konferenz der Kultusminister der Länder in der Bundesrepublik Deutschland (2004). Abiturnoten im Ländervergleich 2002.

Sekretariat der Ständigen Konferenz der Kultusminister der Länder in der Bundesrepublik Deutschland (2005). Abiturnoten im Ländervergleich 2003.

Sekretariat der Ständigen Konferenz der Kultusminister der Länder in der Bundesrepublik Deutschland (2006). Abiturnoten im Ländervergleich 2004.

Sekretariat der Ständigen Konferenz der Kultusminister der Länder in der Bundesrepublik Deutschland (2007). Abiturnoten im Ländervergleich 2005.

Statistisches Bundesamt (2005), Nichtmonetäre hochschulstatistische Kennzahlen, 1980-2003, Fachserie 11 Reihe 4.3.1, Wiesbaden.

Statistisches Bundesamt (2008), Nichtmonetäre hochschulstatistische Kennzahlen, 1980-2007, Fachserie 11 Reihe 4.3.1, Wiesbaden.

Steedman, H. (1993), The Economics of Youth Training in Germany. The Economic Journal, 103 (420), 1279-1291.

Woessman, L. (2003), Schooling Resources, Educational Institutions and Student Performance: the International Evidence. Oxford Bulletin of Economics and Statistics, 65 (2), 1468-1484. 
Figure 1. Trends in the share of graduates from academic high school related to the agespecific cohort between Baden-Württemberg and the control states by gender, in percent

Panel A: Males

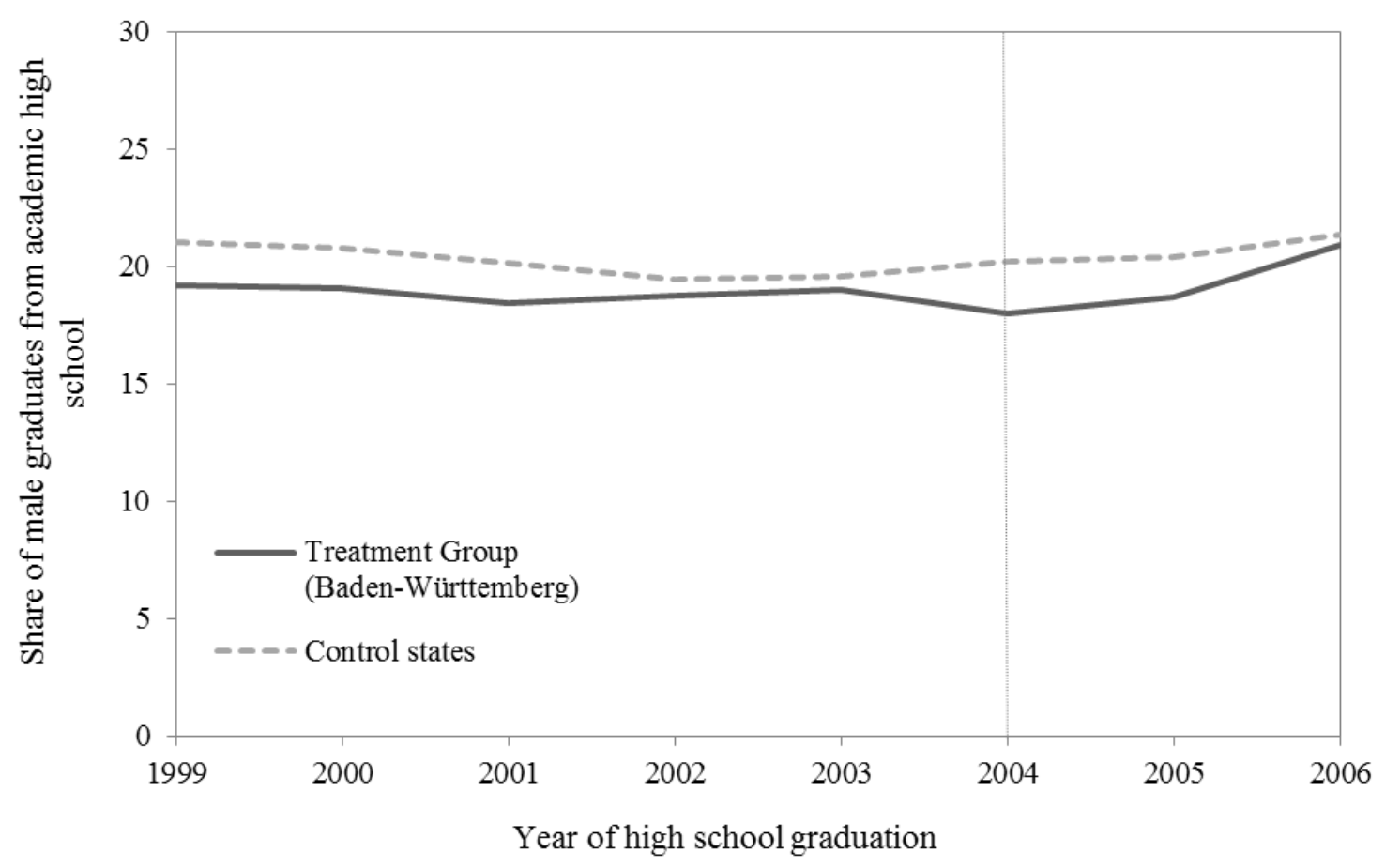

Panel B: Females

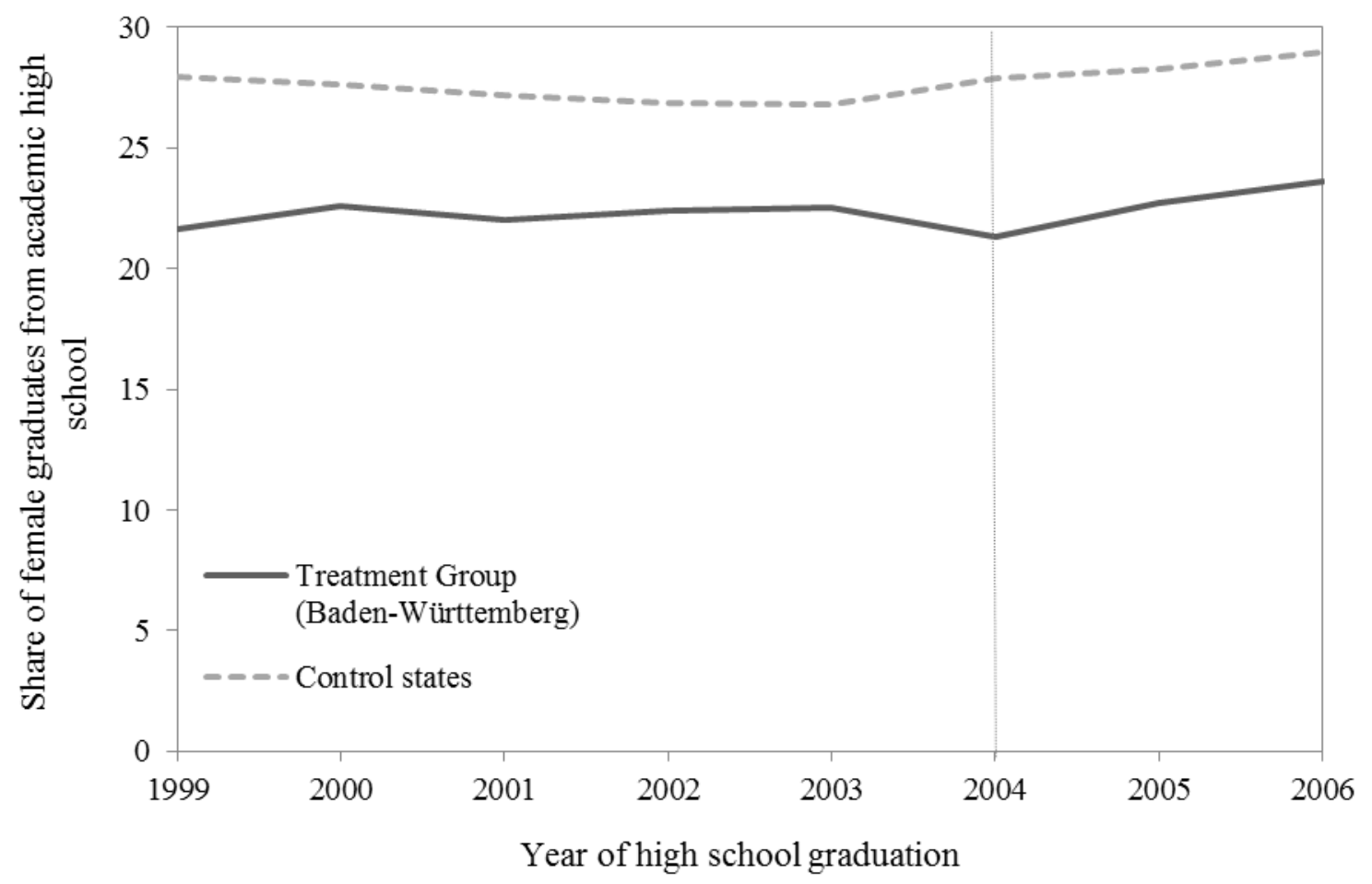

Source: Register of high school graduates combined with data on the age-specific cohort. 
Figure 2. Trends in the share of graduates from vocational high school related to the age-specific cohort between Baden-Württemberg and the control states by gender, in percent

\section{Panel A: Males}

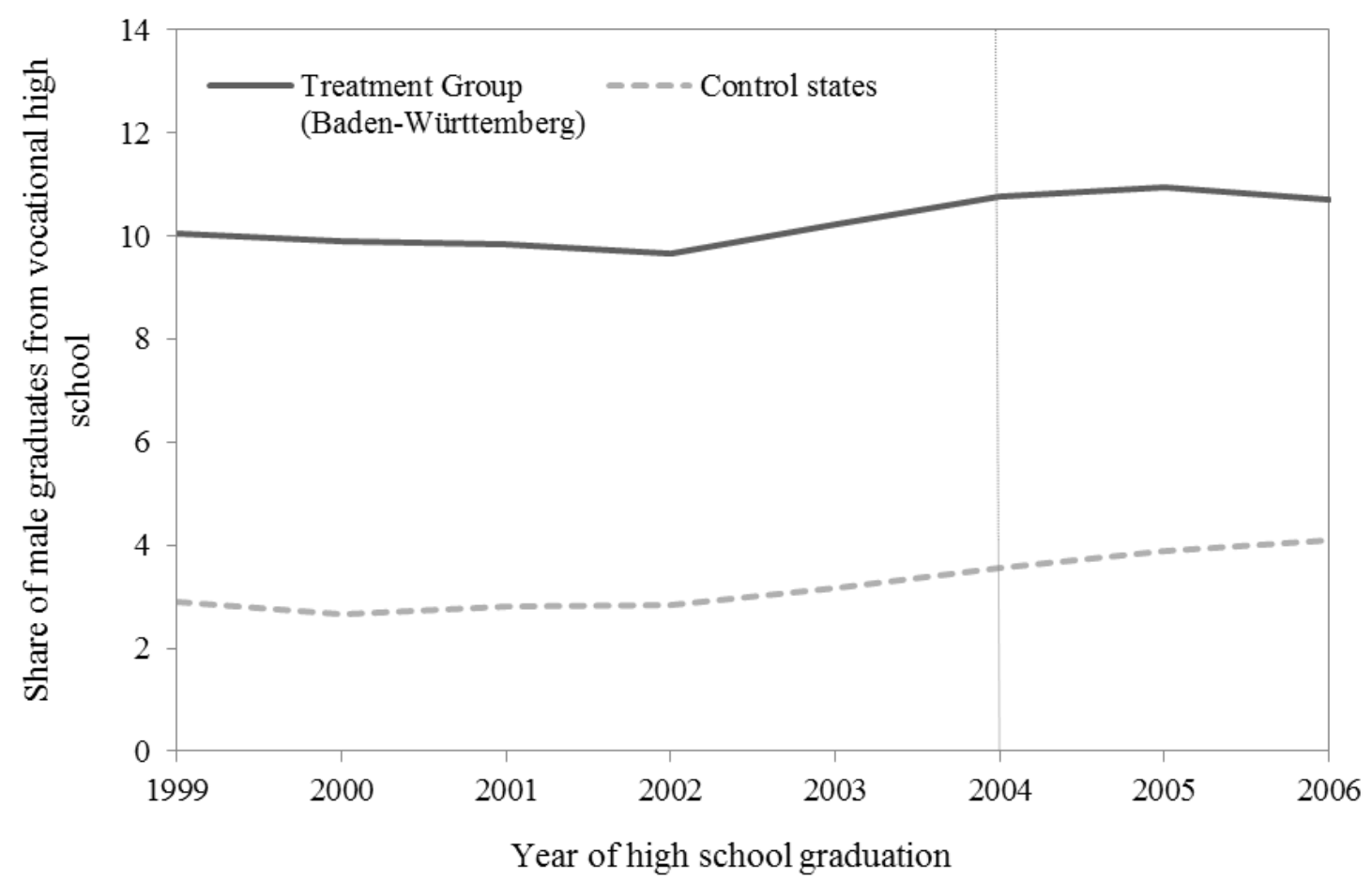

Panel B: Females

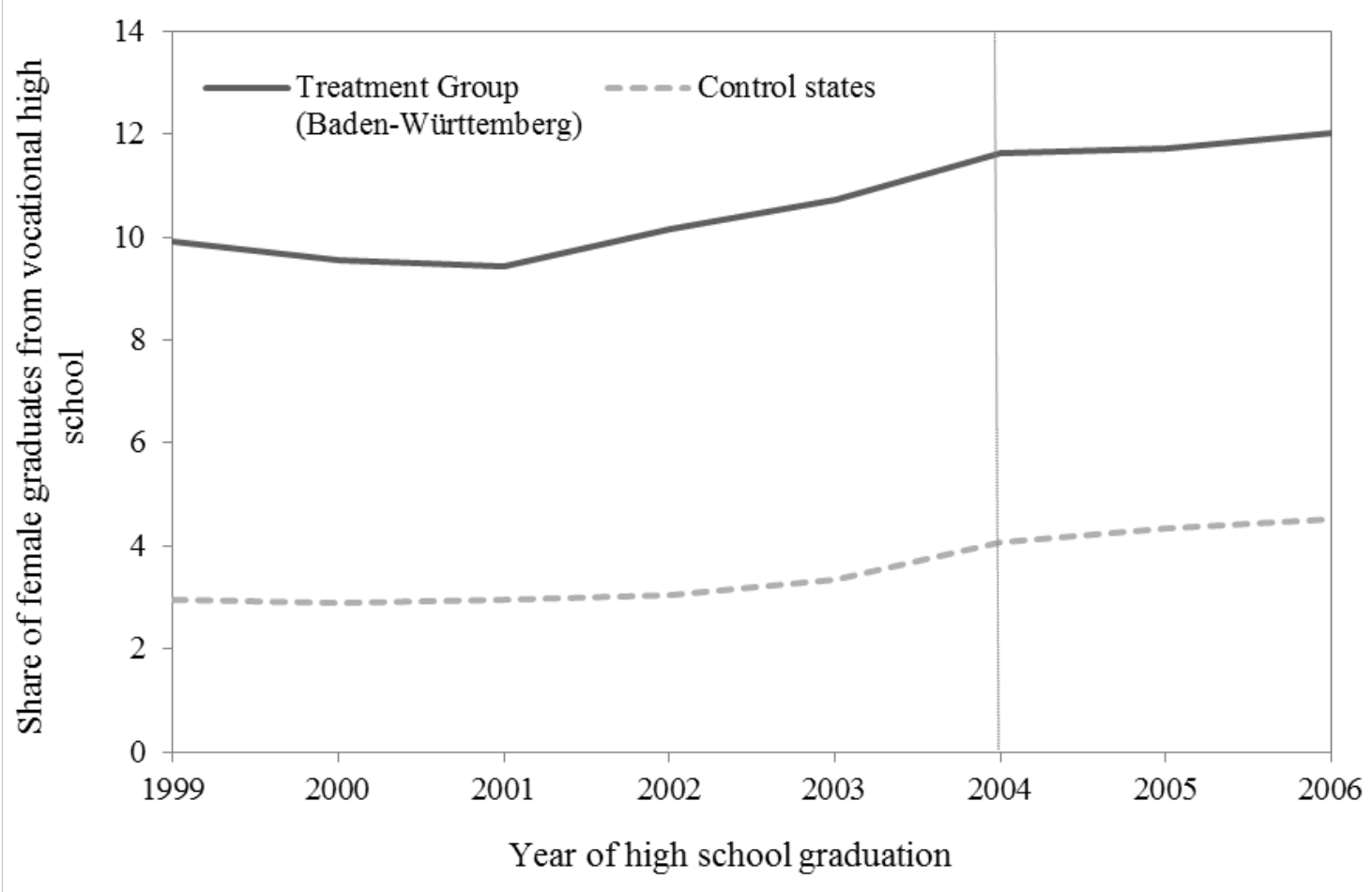

Source: Register of high school graduates combined with data on the age-specific cohort. 
Table 1. Major changes in the curriculum of Baden-Württemberg

\begin{tabular}{lll}
\hline \multicolumn{1}{c}{ Before the reform } & & \multicolumn{1}{c}{ After the reform } \\
\cline { 1 - 1 } Minimum instruction of 26 hours a week & & Minimum instruction of 30 hours a week \\
German, a foreign language and mathe- & & $\begin{array}{l}\text { German, a foreign language and mathe- } \\
\text { matics on a basic level for } 3 \text { hours/ week }\end{array}$
\end{tabular}




\section{Males}

Probabiltiy of graduating from academic high school

Probabiltiy of graduating from academic high school in Baden-Württemberg

$\begin{array}{cc}3,322,472 & 0.20 \\ 483,864 & 0.19 \\ 2,838,608 & 0.20\end{array}$

Probabiltiy of graduating from academic high school in control states

$2,838,608$

Probabiltiy of graduating from vocational high school

$3,322,472$

0.04

Probabiltiy of graduating from vocational high school in Baden-Württemberg

483,864

0.10

Probabiltiy of graduating from vocational high school in control states

$2,838,608$

\section{Females}

Probabiltiy of graduating from academic high school

Probabiltiy of graduating from academic high school in Baden-Württemberg

Probabiltiy of graduating from academic high school in control states

472,326

Probabiltiy of graduating from vocational high school

Probabiltiy of graduating from vocational high school in Baden-Württemberg

Source: Register of high school graduates combined with data on the age-specific cohort. 
Table 3. The effects of the curriculum reform on high school attendance

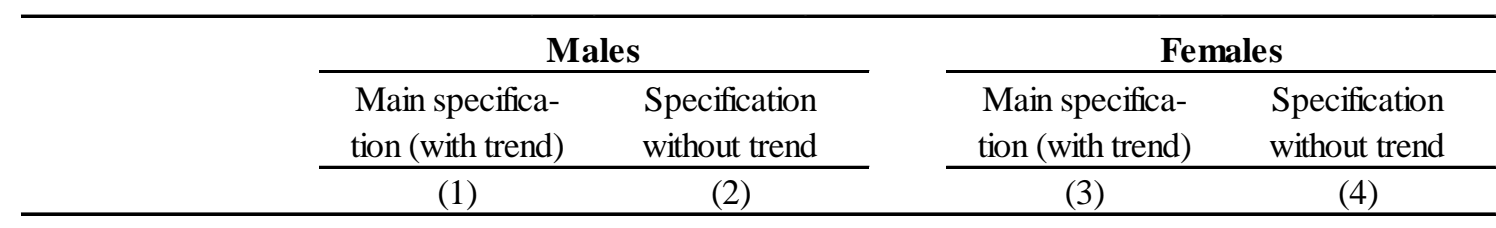

Panel A- Dependent variable: Probability to graduate from academic high school

\begin{tabular}{|c|c|c|c|c|}
\hline$\beta_{03}($ effect in '03) & $\begin{array}{r}0.0008 \\
(0.0043)\end{array}$ & $\begin{array}{r}0.0016 \\
(0.0028)\end{array}$ & $\begin{array}{c}-0.0036 \\
(0.0037)\end{array}$ & $\begin{array}{r}0.0015 \\
(0.0027)\end{array}$ \\
\hline$\beta_{04}($ effect in '04) & $\begin{array}{l}-0.0195 * * * \\
(0.0053)\end{array}$ & $\begin{array}{l}-0.0153 * * * \\
(0.0026)\end{array}$ & $\begin{array}{l}-0.0310 * * * \\
(0.0049)\end{array}$ & $\begin{array}{l}-0.0208 * * * \\
(0.0027)\end{array}$ \\
\hline$\beta_{05}($ effect in '05) & $\begin{array}{l}-0.0177 * * * \\
(0.0067)\end{array}$ & $\begin{array}{l}-0.0100 * * * \\
(0.0029)\end{array}$ & $\begin{array}{l}-0.0263 * * * \\
(0.0066)\end{array}$ & $\begin{array}{l}-0.0112 * * \\
(0.0034)\end{array}$ \\
\hline$\beta_{06}($ effect in '06) & $\begin{array}{r}-0.0084 \\
(0.0078)\end{array}$ & $\begin{array}{r}0.0026 \\
(0.0027)\end{array}$ & $\begin{array}{l}-0.0296 * * * \\
(0.0080)\end{array}$ & $\begin{array}{l}-0.0094 * * \\
(0.0035)\end{array}$ \\
\hline Time trend & $\begin{array}{l}0.0034 * * * \\
(0.0013)\end{array}$ & No & $\begin{array}{l}0.0050 * * * \\
(0.0015)\end{array}$ & No \\
\hline State fixed effects & Yes & Yes & Yes & Yes \\
\hline Year fixed effects & Yes & Yes & Yes & Yes \\
\hline
\end{tabular}

Panel B- Dependent variable: Probability to graduate from vocational high school

\begin{tabular}{|c|c|c|c|c|}
\hline$\beta_{03}$ (effect in '03) & $\begin{array}{l}0.0030 * * * \\
(0.0011)\end{array}$ & $\begin{array}{l}0.0024 * * * \\
(0.0007)\end{array}$ & $\begin{array}{r}0.0048 \\
(0.0031)\end{array}$ & $\begin{array}{l}0.0022 * * * \\
(0.0006)\end{array}$ \\
\hline$\beta_{04}($ effect in '04) & $\begin{array}{l}0.0055 * * * \\
(0.0016)\end{array}$ & $\begin{array}{l}0.0037 * * * \\
(0.0010)\end{array}$ & $\begin{array}{r}0.0066 \\
(0.0042)\end{array}$ & $\begin{array}{l}0.0042 \text { *** } \\
(0.0011)\end{array}$ \\
\hline$\beta_{05}$ (effect in '05) & $\begin{array}{l}0.0055 * * * \\
(0.0019)\end{array}$ & $\begin{array}{l}0.0025 * * \\
(0.0010)\end{array}$ & $\begin{array}{r}0.0047 \\
(0.0052)\end{array}$ & $\begin{array}{l}0.0026 \text { ** } \\
(0.0010)\end{array}$ \\
\hline$\beta_{06}$ (effect in '06) & $\begin{array}{r}0.0020 \\
(0.0023)\end{array}$ & $\begin{array}{l}-0.0022 \\
(0.0011)\end{array}$ & $\begin{array}{r}0.0056 \\
(0.0062)\end{array}$ & $\begin{array}{l}0.0038 * * * \\
(0.0011)\end{array}$ \\
\hline Time trend & $\begin{array}{l}-0.0012 * * * \\
(0.0004)\end{array}$ & No & $\begin{array}{r}0.0002 \\
(0.0010)\end{array}$ & No \\
\hline State fixed effects & Yes & Yes & Yes & Yes \\
\hline Year fixed effects & Yes & Yes & Yes & Yes \\
\hline Observations & $3,322,472$ & $3,322,472$ & $3,185,002$ & $3,185,002$ \\
\hline
\end{tabular}

Source: Register of high school graduates combined with data on the age-specific cohort.

Notes: The dependent variable in Panel A is a binary variable that indicates graduating from academic high school (1) or not (0). The dependent variable in Panel B is a binary variable that indicates graduating from vocational high school (1) or not (0). Column 1 and 3 represent the specifications as reported in equation (1) and column 2 and 4 those from equation (2). The estimations were run by Ordinary Least Squares. The standard errors are shown in parentheses. For all specifications, standard errors are clustered at the year-state level (104 clusters).

$$
\begin{aligned}
& * * p<0.05 \\
& * * * p<0.01
\end{aligned}
$$


Table 4. Alternative calculation of standard errors

\begin{tabular}{|c|c|c|c|c|c|c|c|c|}
\hline & \multicolumn{4}{|c|}{ Males } & \multicolumn{4}{|c|}{ Females } \\
\hline & $\begin{array}{c}\text { Main } \\
\text { Specification } \\
(1) \\
\end{array}$ & $\begin{array}{l}\text { State } \\
\text { cluster } \\
(2) \\
\end{array}$ & $\begin{array}{c}\text { State-pre/post } \\
\text { cluster } \\
(3) \\
\end{array}$ & $\begin{array}{c}\text { Five region } \\
\text { cluster (4 df) } \\
(4)\end{array}$ & $\begin{array}{c}\text { Main } \\
\text { Specification } \\
(5) \\
\end{array}$ & $\begin{array}{c}\text { State } \\
\text { cluster } \\
(6) \\
\end{array}$ & $\begin{array}{c}\text { State-pre/post } \\
\text { cluster } \\
(7) \\
\end{array}$ & $\begin{array}{c}\text { Five region } \\
\text { cluster (4 df) } \\
(8) \\
\end{array}$ \\
\hline \multicolumn{9}{|c|}{ Panel A- Dependent variable: Probability to graduate from academic high school } \\
\hline$\beta_{03}($ effect in '03) & $\begin{array}{r}0.0008 \\
(0.0043)\end{array}$ & $\begin{array}{r}0.0008 \\
(0.0020)\end{array}$ & $\begin{array}{r}0.0008 \\
(0.0029)\end{array}$ & $\begin{array}{r}0.0008 \\
(0.0022)\end{array}$ & $\begin{array}{l}-0.0036 \\
(0.0037)\end{array}$ & $\begin{array}{l}-0.0036 \\
(0.0028)\end{array}$ & $\begin{array}{r}-0.0036 \\
(0.0029)\end{array}$ & $\begin{array}{l}-0.0036 \\
(0.0023)\end{array}$ \\
\hline$\beta_{04}($ effect in '04) & $\begin{array}{l}-0.0195 * * * \\
(0.0053)\end{array}$ & $\begin{array}{l}-0.0195 * * * \\
(0.0037)\end{array}$ & $\begin{array}{l}-0.0195 * * * \\
(0.0039)\end{array}$ & $\begin{array}{l}-0.0195 * * * \\
(0.0038)\end{array}$ & $\begin{array}{l}-0.0310 * * * \\
(0.0049)\end{array}$ & $\begin{array}{l}-0.0310 * * * \\
(0.0033)\end{array}$ & $\begin{array}{l}-0.0310 * * * \\
(0.0040)\end{array}$ & $\begin{array}{l}-0.0310 * * * \\
(0.0032)\end{array}$ \\
\hline$\beta_{05}($ effect in '05) & $\begin{array}{l}-0.0177 * * * \\
(0.0067)\end{array}$ & $\begin{array}{l}-0.0177 * * * \\
(0.0047)\end{array}$ & $\begin{array}{l}-0.0177 * * * \\
(0.0052)\end{array}$ & $\begin{array}{l}-0.0177 * * \\
(0.0044)\end{array}$ & $\begin{array}{l}-0.0263 * * * \\
(0.006)\end{array}$ & $\begin{array}{l}-0.0263 * * * \\
(0.0050)\end{array}$ & $\begin{array}{l}-0.0263 * * * \\
(0.0056)\end{array}$ & $\begin{array}{l}-0.0263 * * * \\
(0.0045)\end{array}$ \\
\hline$\beta_{06}($ effect in '06) & $\begin{array}{l}-0.0084 \\
(0.0078)\end{array}$ & $\begin{array}{l}-0.0084 \\
(0.0068)\end{array}$ & $\begin{array}{l}-0.0084 \\
(0.0062)\end{array}$ & $\begin{array}{l}-0.0084 \\
(0.0070)\end{array}$ & $\begin{array}{l}-0.0296 * * * \\
(0.0080)\end{array}$ & $\begin{array}{l}-0.0296 * * * \\
(0.0056)\end{array}$ & $\begin{array}{l}-0.0296 * * * \\
(0.0068)\end{array}$ & $\begin{array}{l}-0.0296 * * * \\
(0.0044)\end{array}$ \\
\hline \multicolumn{9}{|c|}{ Panel B- Dependent variable: Probability to graduate from vocational high school } \\
\hline$\beta_{03}($ effect in '03) & $\begin{array}{l}0.0030 * * * \\
(0.0011)\end{array}$ & $\begin{array}{l}0.0030 * * * \\
(0.0007)\end{array}$ & $\begin{array}{l}0.0030 * * * \\
(0.0008)\end{array}$ & $\begin{array}{l}0.0030 \text { *** } \\
(0.0006)\end{array}$ & $\begin{array}{l}0.0022 \text { *** } \\
(0.0006)\end{array}$ & $\begin{array}{l}0.0022 \text { *** } \\
(0.0007)\end{array}$ & $\begin{array}{l}0.0022 \text { *** } \\
(0.0006)\end{array}$ & $\begin{array}{l}0.0022 \text { ** } \\
(0.0006)\end{array}$ \\
\hline$\beta_{04}($ effect in '04) & $\begin{array}{l}0.0055 \text { *** } \\
(0.0016)\end{array}$ & $\begin{array}{l}0.0055 * * * \\
(0.0013)\end{array}$ & $\begin{array}{l}0.0055 \text { *** } \\
(0.0011)\end{array}$ & $\begin{array}{l}0.0055 \text { *** } \\
(0.0008)\end{array}$ & $\begin{array}{l}0.0042 \text { *** } \\
(0.0011)\end{array}$ & $\begin{array}{l}0.0042 \text { *** } \\
(0.0014)\end{array}$ & $\begin{array}{l}0.0042 \text { *** } \\
(0.0011)\end{array}$ & $\begin{array}{l}0.0042 \text { ** } \\
(0.0011)\end{array}$ \\
\hline$\beta_{05}($ effect in '05) & $\begin{array}{l}0.0055^{* * *} \\
(0.0019)\end{array}$ & $\begin{array}{l}0.0055 * * * \\
(0.0015)\end{array}$ & $\begin{array}{l}0.0055 * * * \\
(0.0012)\end{array}$ & $\begin{array}{l}0.0055 * * \\
(0.0014)\end{array}$ & $\begin{array}{l}0.0026 \text { ** } \\
(0.0010)\end{array}$ & $\begin{array}{r}0.0026 \\
(0.0012)\end{array}$ & $\begin{array}{l}0.0026 \text { ** } \\
(0.0010)\end{array}$ & $\begin{array}{l}0.0026 * * \\
(0.0006)\end{array}$ \\
\hline$\beta_{06}($ effect in '06) & $\begin{array}{r}0.0020 \\
(0.0023)\end{array}$ & $\begin{array}{r}0.0020 \\
(0.0017)\end{array}$ & $\begin{array}{r}0.0020 \\
(0.0014)\end{array}$ & $\begin{array}{r}0.0020 \\
(0.0023)\end{array}$ & $\begin{array}{l}0.0038 * * * \\
(0.0011)\end{array}$ & $\begin{array}{c}0.0038 \text { ** } \\
(0.0014)\end{array}$ & $\begin{array}{l}0.0038 * * * \\
(0.0011)\end{array}$ & $\begin{array}{r}0.0038 \\
(0.0014)\end{array}$ \\
\hline
\end{tabular}

Source: Register of high school graduates combined with data on the age-specific cohort.

Notes: Results are shown from equation (1) for Panel A and B for males and for Panel A for females. For females, the results for Panel B are based on equation (2). For further notes on the estimation, see the notes in Table 3. Column 2 to 4 and 6 to 8 contain three alternative methods for statistical inference for males and females, respectively. These are clustering at the state level, clustering at the state and pre/post level and clustering at the five region level.

$* * p<0.05$
$* * * p<0.01$ 
Table 5. Results for males when excluding one state at a time from the control states

\begin{tabular}{|c|c|c|c|c|c|c|c|c|c|c|c|c|}
\hline & \multicolumn{12}{|c|}{ Excluded state } \\
\hline & Bavaria & Berlin & $\begin{array}{c}\text { Branden- } \\
\text { burg }\end{array}$ & Bremen & $\begin{array}{l}\text { Ham- } \\
\text { burg }\end{array}$ & Lower Saxony & $\begin{array}{c}\text { North Rhine- } \\
\text { Westphalia }\end{array}$ & $\begin{array}{c}\text { Rhineland- } \\
\text { Palatine }\end{array}$ & $\begin{array}{l}\text { Saar- } \\
\text { land }\end{array}$ & Saxony & $\begin{array}{c}\text { Schleswig- } \\
\text { Holstein }\end{array}$ & Thuringia \\
\hline \multicolumn{13}{|c|}{ Panel A- Dependent variable: Probability to graduate from academic high school } \\
\hline$\beta_{03}$ (effect in '03) & $\begin{array}{r}0.0004 \\
(0.0044)\end{array}$ & $\begin{array}{r}0.0003 \\
(0.0043)\end{array}$ & $\begin{array}{r}0.0004 \\
(0.0045)\end{array}$ & $\begin{array}{r}0.0010 \\
(0.0043)\end{array}$ & $\begin{array}{r}0.0010 \\
(0.0044)\end{array}$ & $\begin{array}{r}0.0016 \\
(0.0049)\end{array}$ & $\begin{array}{r}0.0026 \\
(0.0023)\end{array}$ & $\begin{array}{r}0.0004 \\
(0.0044)\end{array}$ & $\begin{array}{r}0.0009 \\
(0.0043)\end{array}$ & $\begin{array}{l}-0.0002 \\
(0.0043)\end{array}$ & $\begin{array}{r}0.0007 \\
(0.0044)\end{array}$ & $\begin{array}{r}0.0013 \\
(0.0044)\end{array}$ \\
\hline$\beta_{04}$ (effect in '04) & $\begin{array}{l}-0.0220 * * * \\
(0.0057)\end{array}$ & $\begin{array}{l}-0.0195 * * * \\
(0.0053)\end{array}$ & $\begin{array}{l}-0.0197 * * * \\
(0.0056)\end{array}$ & $\begin{array}{l}-0.0196 * * * \\
(0.0054)\end{array}$ & $\begin{array}{l}-0.0194 * * * \\
(0.0056)\end{array}$ & $\begin{array}{l}-0.0194 * * * \\
(0.0062)\end{array}$ & $\begin{array}{l}-0.0158 * * * \\
(0.0027)\end{array}$ & $\begin{array}{l}-0.0199 * * * \\
(0.0055)\end{array}$ & $\begin{array}{l}-0.0194 * * * \\
(0.0053)\end{array}$ & $\begin{array}{l}-0.0203 * * * \\
(0.0053)\end{array}$ & $\begin{array}{l}-0.0198 * * * \\
(0.0055)\end{array}$ & $\begin{array}{l}-0.0185 * * * \\
(0.0055)\end{array}$ \\
\hline$\beta_{05}$ (effect in '05) & $\begin{array}{l}-0.0208^{* * *} \\
(0.0072)\end{array}$ & $\begin{array}{l}-0.0178 \text { ** } \\
(0.0067)\end{array}$ & $\begin{array}{l}-0.0186 \text { ** } \\
(0.0071)\end{array}$ & $\begin{array}{l}-0.0175 * * \\
(0.0068)\end{array}$ & $\begin{array}{l}-0.0174 * * \\
(0.0069)\end{array}$ & $\begin{array}{l}-0.0164 * * \\
(0.0077)\end{array}$ & $\begin{array}{l}-0.0135 * * \\
(0.0033)\end{array}$ & $\begin{array}{l}-0.0184 \text { *** } \\
(0.0069)\end{array}$ & $\begin{array}{l}-0.0177^{* * *} \\
(0.0067)\end{array}$ & $\begin{array}{l}-0.0186 * * * \\
(0.0067)\end{array}$ & $\begin{array}{l}-0.0183 * * * \\
(0.0068)\end{array}$ & $\begin{array}{l}-0.0164 * * \\
(0.0069)\end{array}$ \\
\hline$\beta_{06}$ (effect in '06) & $\begin{array}{l}-0.0125 \\
(0.0083)\end{array}$ & $\begin{array}{l}-0.0086 \\
(0.0079)\end{array}$ & $\begin{array}{l}-0.0093 \\
(0.0083)\end{array}$ & $\begin{array}{l}-0.0083 \\
(0.0079)\end{array}$ & $\begin{array}{l}-0.0080 \\
(0.0081)\end{array}$ & $\begin{array}{l}-0.0081 \\
(0.0091)\end{array}$ & $\begin{array}{l}-0.0012 \\
(0.0038)\end{array}$ & $\begin{array}{l}-0.0095 \\
(0.0080)\end{array}$ & $\begin{array}{l}-0.0082 \\
(0.0078)\end{array}$ & $\begin{array}{l}-0.0098 \\
(0.0078)\end{array}$ & $\begin{array}{c}-0.0092 \\
(0.0080)\end{array}$ & $\begin{array}{l}-0.0071 \\
(0.0081)\end{array}$ \\
\hline \multicolumn{13}{|c|}{ Panel B- Dependent variable: Probability to graduate from vocational high school } \\
\hline$\beta_{03}$ (effect in '03) & $\begin{array}{l}0.0028 \text { *** } \\
(0.0010)\end{array}$ & $\begin{array}{l}0.0032 \text { *** } \\
(0.0011)\end{array}$ & $\begin{array}{l}0.0028 \text { ** } \\
(0.0011)\end{array}$ & $\begin{array}{l}0.0030 * * * \\
(0.0011)\end{array}$ & $\begin{array}{l}0.0032 \text { *** } \\
(0.0011)\end{array}$ & $\begin{array}{l}0.0031 * * * \\
(0.0011)\end{array}$ & $\begin{array}{l}0.0025 \text { ** } \\
(0.0013)\end{array}$ & $\begin{array}{l}0.0029 * * \\
(0.0012)\end{array}$ & $\begin{array}{l}0.0030 \text { *** } \\
(0.0011)\end{array}$ & $\begin{array}{l}0.0035 \text { *** } \\
(0.0010)\end{array}$ & $\begin{array}{l}0.0031 \text { *** } \\
(0.0011)\end{array}$ & $\begin{array}{l}0.0029 * * * \\
(0.0011)\end{array}$ \\
\hline$\beta_{04}$ (effect in '04) & $\begin{array}{l}0.0047^{* * *} \\
(0.0016)\end{array}$ & $\begin{array}{l}0.0053 \text { *** } \\
(0.0016)\end{array}$ & $\begin{array}{l}0.0054 \text { *** } \\
(0.0016)\end{array}$ & $\begin{array}{l}0.0056 \text { *** } \\
(0.0016)\end{array}$ & $\begin{array}{l}0.0055^{* * *} \\
(0.0016)\end{array}$ & $\begin{array}{l}0.0057 \text { *** } \\
(0.0016)\end{array}$ & $\begin{array}{l}0.0058 \text { *** } \\
(0.0020)\end{array}$ & $\begin{array}{l}0.0051 \text { *** } \\
(0.0017)\end{array}$ & $\begin{array}{l}0.0056 \text { *** } \\
(0.0016)\end{array}$ & $\begin{array}{l}0.0064 * * * \\
(0.0013)\end{array}$ & $\begin{array}{l}0.0059 \text { *** } \\
(0.0016)\end{array}$ & $\begin{array}{l}0.0052 \text { *** } \\
(0.0016)\end{array}$ \\
\hline$\beta_{05}$ (effect in '05) & $\begin{array}{l}0.0045 \text { ** } \\
(0.0019)\end{array}$ & $\begin{array}{l}0.0054 \text { *** } \\
(0.0019)\end{array}$ & $\begin{array}{l}0.0049 * * \\
(0.0019)\end{array}$ & $\begin{array}{l}0.0057 \text { *** } \\
(0.0020)\end{array}$ & $\begin{array}{l}0.0057 \text { *** } \\
(0.0020)\end{array}$ & $\begin{array}{l}0.0062 * * * \\
(0.0019)\end{array}$ & $\begin{array}{l}0.0057 \text { ** } \\
(0.0025)\end{array}$ & $\begin{array}{l}0.0050 \text { ** } \\
(0.0020)\end{array}$ & $\begin{array}{l}0.0055^{* * *} \\
(0.0019)\end{array}$ & $\begin{array}{l}0.0062 * * * \\
(0.0017)\end{array}$ & $\begin{array}{l}0.0059 * * * \\
(0.0019)\end{array}$ & $\begin{array}{l}0.0053 \text { *** } \\
(0.0019)\end{array}$ \\
\hline$\beta_{06}($ effect in '06) & $\begin{array}{r}0.0007 \\
(0.0023)\end{array}$ & $\begin{array}{r}0.0022 \\
(0.0023)\end{array}$ & $\begin{array}{r}0.0015 \\
(0.0024)\end{array}$ & $\begin{array}{r}0.0022 \\
(0.0024)\end{array}$ & $\begin{array}{r}0.0023 \\
(0.0024)\end{array}$ & $\begin{array}{r}0.0030 \\
(0.0023)\end{array}$ & $\begin{array}{r}0.0017 \\
(0.0030)\end{array}$ & $\begin{array}{r}0.0021 \\
(0.0024)\end{array}$ & $\begin{array}{r}0.0020 \\
(0.0024)\end{array}$ & $\begin{array}{r}0.0022 \\
(0.0021)\end{array}$ & $\begin{array}{r}0.0024 \\
(0.0023)\end{array}$ & $\begin{array}{r}0.0017 \\
(0.0023)\end{array}$ \\
\hline
\end{tabular}

Source: Register of high school graduates combined with data on the age-specific cohort.

Notes: The results are estimated based on equation (1) with the difference that in each regression one state is excluded when defining the control group. For further notes on the estimation, see the notes in Table 3 for column (1) and (3).

$$
\begin{aligned}
& * * p<0.05 \\
& * * * p<0.01
\end{aligned}
$$


Table 6. Results for females when excluding one state at a time from the control states

\begin{tabular}{|c|c|c|c|c|c|c|c|c|c|c|c|c|}
\hline & \multicolumn{12}{|c|}{ Excluded state } \\
\hline & Bavaria & Berlin & $\begin{array}{c}\text { Branden- } \\
\text { burg }\end{array}$ & Bremen & $\begin{array}{r}\text { Ham- } \\
\text { burg }\end{array}$ & Lower Saxony & $\begin{array}{l}\text { North Rhine- } \\
\text { Westphalia }\end{array}$ & $\begin{array}{l}\text { Rhineland- } \\
\text { Palatine }\end{array}$ & $\begin{array}{l}\text { Saar- } \\
\text { land }\end{array}$ & Saxony & $\begin{array}{l}\text { Schleswig- } \\
\text { Holstein }\end{array}$ & Thuringia \\
\hline \multicolumn{13}{|c|}{ Panel A- Dependent variable: Probability to graduate from academic high school } \\
\hline$\beta_{03}($ effect in '03) & $\begin{array}{r}-0.0048 \\
(0.0041)\end{array}$ & $\begin{array}{r}-0.0034 \\
(0.0038)\end{array}$ & $\begin{array}{l}-0.0049 \\
(0.0038)\end{array}$ & $\begin{array}{l}-0.0037 \\
(0.0037)\end{array}$ & $\begin{array}{l}-0.0034 \\
(0.0037)\end{array}$ & $\begin{array}{r}-0.0029 \\
(0.0040)\end{array}$ & $\begin{array}{r}-0.0046 \\
(0.0045)\end{array}$ & $\begin{array}{r}-0.0028 \\
(0.0039)\end{array}$ & $\begin{array}{r}-0.0035 \\
(0.0037)\end{array}$ & $\begin{array}{l}-0.0044 \\
(0.0033)\end{array}$ & $\begin{array}{r}-0.0036 \\
(0.0039)\end{array}$ & $\begin{array}{l}-0.0019 \\
(0.0036)\end{array}$ \\
\hline$\beta_{04}$ (effect in '04) & $\begin{array}{l}-0.0335 * * * \\
(0.0055)\end{array}$ & $\begin{array}{l}-0.0308 * * * \\
(0.0051)\end{array}$ & $\begin{array}{l}-0.0313 * * * \\
(0.0051)\end{array}$ & $\begin{array}{l}-0.0314 * * * \\
(0.0050)\end{array}$ & $\begin{array}{l}-0.0306 * * * \\
(0.0050)\end{array}$ & $\begin{array}{l}-0.0305 * * * \\
(0.0054)\end{array}$ & $\begin{array}{l}-0.0311 * * * \\
(0.0061)\end{array}$ & $\begin{array}{l}-0.0307 * * * \\
(0.0052)\end{array}$ & $\begin{array}{l}-0.0312 * * * \\
(0.0050)\end{array}$ & $\begin{array}{l}-0.0312 * * * \\
(0.0042)\end{array}$ & $\begin{array}{l}-0.0310 * * * \\
(0.0052)\end{array}$ & $\begin{array}{l}-0.0286 * * * \\
(0.0048)\end{array}$ \\
\hline$\beta_{05}($ effect in '05) & $\begin{array}{l}-0.0302 * * * \\
(0.0074)\end{array}$ & $\begin{array}{l}-0.0253 * * * \\
(0.0068)\end{array}$ & $\begin{array}{l}-0.0283 * * * \\
(0.0068)\end{array}$ & $\begin{array}{l}-0.0266 * * * \\
(0.0067)\end{array}$ & $\begin{array}{l}-0.0259 * * * \\
(0.0067)\end{array}$ & $\begin{array}{l}-0.0253 * * * \\
(0.0071)\end{array}$ & $\begin{array}{l}-0.0266 * * * \\
(0.0083)\end{array}$ & $\begin{array}{l}-0.0257 * * * \\
(0.0070)\end{array}$ & $\begin{array}{l}-0.0264 * * * \\
(0.0067)\end{array}$ & $\begin{array}{l}-0.0260 * * \\
(0.0058)\end{array}$ & $\begin{array}{l}-0.0261 * * * \\
(0.0069)\end{array}$ & $\begin{array}{l}-0.0234 * * \\
(0.0065)\end{array}$ \\
\hline$\beta_{06}($ effect in '06) & $\begin{array}{l}-0.0334 * * * \\
(0.0089)\end{array}$ & $\begin{array}{l}-0.0296 * * * \\
(0.0082)\end{array}$ & $\begin{array}{l}-0.0315 * * * \\
(0.0082)\end{array}$ & $\begin{array}{l}-0.0301 * * * \\
(0.0081)\end{array}$ & $\begin{array}{l}-0.0289 * * * \\
(0.0081)\end{array}$ & $\begin{array}{l}-0.0309 * * * \\
(0.0086)\end{array}$ & $\begin{array}{l}-0.0287 \text { *** } \\
(0.0097)\end{array}$ & $\begin{array}{l}-0.0288 * * * \\
(0.0084)\end{array}$ & $\begin{array}{l}-0.0292 * * * \\
(0.0081)\end{array}$ & $\begin{array}{l}-0.0289 * * * \\
(0.0067)\end{array}$ & $\begin{array}{l}-0.0295 * * * \\
(0.0084)\end{array}$ & $\begin{array}{l}-0.0257^{* *} \\
(0.0078)\end{array}$ \\
\hline \multicolumn{13}{|c|}{ Panel B- Dependent variable: Probability to graduate from vocational high school } \\
\hline$\beta_{03}($ effect in '03) & $\begin{array}{l}0.00211^{* * *} \\
(0.0007)\end{array}$ & $\begin{array}{l}0.0025 * * * \\
(0.0006)\end{array}$ & $\begin{array}{l}0.0020 * * * \\
(0.0006)\end{array}$ & $\begin{array}{l}0.0023 * * * \\
(0.0006)\end{array}$ & $\begin{array}{l}0.0022 * * * \\
(0.0006)\end{array}$ & $\begin{array}{l}0.0026 * * * \\
(0.0006)\end{array}$ & $\begin{array}{l}0.0018 \text { ** } \\
(0.0007)\end{array}$ & $\begin{array}{l}0.0021 \text { *** } \\
(0.0006)\end{array}$ & $\begin{array}{l}0.0022 * * * \\
(0.0006)\end{array}$ & $\begin{array}{l}0.0026 * * * \\
(0.0005)\end{array}$ & $\begin{array}{l}0.0022 \text { *** } \\
(0.0006)\end{array}$ & $\begin{array}{l}0.0024 * * * \\
(0.0006)\end{array}$ \\
\hline$\beta_{04}$ (effect in '04) & $\begin{array}{l}0.0033 \text { *** } \\
(0.0010)\end{array}$ & $\begin{array}{l}0.0041 * * * \\
(0.0012)\end{array}$ & $\begin{array}{l}0.0041 \text { *** } \\
(0.0012)\end{array}$ & $\begin{array}{l}0.0042 * * * \\
(0.0011)\end{array}$ & $\begin{array}{l}0.0042 * * * \\
(0.0012)\end{array}$ & $\begin{array}{l}0.0047^{* * *} \\
(0.0012)\end{array}$ & $\begin{array}{l}0.0045 * * * \\
(0.0015)\end{array}$ & $\begin{array}{l}0.0037 * * * \\
(0.0011)\end{array}$ & $\begin{array}{l}0.0042 * * * \\
(0.0011)\end{array}$ & $\begin{array}{l}0.0050 \text { *** } \\
(0.0011)\end{array}$ & $\begin{array}{l}0.0045 * * * \\
(0.0012)\end{array}$ & $\begin{array}{l}0.0045^{* * *} \\
(0.0012)\end{array}$ \\
\hline$\beta_{05}($ effect in '05) & $\begin{array}{r}0.0022 \\
(0.0012)\end{array}$ & $\begin{array}{l}0.0025 \text { ** } \\
(0.0010)\end{array}$ & $\begin{array}{l}0.0020 * * \\
(0.0009)\end{array}$ & $\begin{array}{l}0.0027 \text { ** } \\
(0.0010)\end{array}$ & $\begin{array}{l}0.0024 \text { ** } \\
(0.0010)\end{array}$ & $\begin{array}{l}0.0029 * * \\
(0.0011)\end{array}$ & $\begin{array}{l}0.0031 \text { ** } \\
(0.0013)\end{array}$ & $\begin{array}{l}0.0022 * * \\
(0.0010)\end{array}$ & $\begin{array}{l}0.0026 \text { ** } \\
(0.0010)\end{array}$ & $\begin{array}{l}0.0033 * * * \\
(0.0010)\end{array}$ & $\begin{array}{l}0.0030 \text { *** } \\
(0.0010)\end{array}$ & $\begin{array}{l}0.0028 * * * \\
(0.0011)\end{array}$ \\
\hline$\beta_{06}$ (effect in '06) & $\begin{array}{l}0.0030 * * \\
(0.0013)\end{array}$ & $\begin{array}{l}0.0039 * * * \\
(0.0012)\end{array}$ & $\begin{array}{l}0.00311^{* * *} \\
(0.0012)\end{array}$ & $\begin{array}{l}0.0040 * * * \\
(0.0011)\end{array}$ & $\begin{array}{l}0.0037 \text { *** } \\
(0.0012)\end{array}$ & $\begin{array}{l}0.0040 * * * \\
(0.0013)\end{array}$ & $\begin{array}{l}0.0031 \text { ** } \\
(0.0015)\end{array}$ & $\begin{array}{l}0.0040 \text { *** } \\
(0.0011)\end{array}$ & $\begin{array}{l}0.0037 * * * \\
(0.0011)\end{array}$ & $\begin{array}{l}0.0044 \text { *** } \\
(0.0011)\end{array}$ & $\begin{array}{l}0.0042 * * * \\
(0.0011)\end{array}$ & $\begin{array}{l}0.00411^{* * *} \\
(0.0011)\end{array}$ \\
\hline
\end{tabular}

Source: Register of high school graduates combined with data on the age-specific cohort.

Notes: The results are estimated based on equation (1) for Panel A and equation (2) for Panel B. The only difference is that in each regression one state is excluded when defining the control group. For further notes on the estimation, see the notes in Table 3 for column (1) and (3).

$$
\begin{aligned}
& * * p<0.05 \\
& * * * p<0.01
\end{aligned}
$$


Table 7. Comparison of the average characteristics of students in academic high school in Baden-Württemberg between 2002 and 2006

\begin{tabular}{llc}
\hline Characteristics & 2002 & 2006 \\
\hline $\begin{array}{l}\text { Students where at least one parent has graduated from high } \\
\text { school }\end{array}$ & $64 \%$ & $65 \%$ \\
$\begin{array}{l}\text { Students where at least one parent has obtainained an university } \\
\text { degree }\end{array}$ & $57 \%$ & $58 \%$ \\
$\begin{array}{l}\text { International Socio-Economic Index of Occupational Status } \\
\text { (ISEI) of parents }\end{array}$ & 61.0 & 61.0 \\
$\begin{array}{l}\text { Students with migration background (either first or second } \\
\text { generation) }\end{array}$ & $20 \%$ & $21 \%$ \\
More than 100 books at home & $86 \%$ & $85 \%$
\end{tabular}

Source: Becker et al. (2010).

Notes: The table summarizes the main findings of Becker et al. (2010) that are based on the analysis of the TOSCA-2002 and TOSCA-2006 studies. The International Socio-Economic Index of Occupational Status was developed by Ganzeboom (1992). 
Table 8. The effects of the curriculum reform on passing the high school exam and on average high school grades

\begin{tabular}{ccc}
\hline $\begin{array}{c}\text { Main Specification } \\
\text { without trend }\end{array}$ & State & Five region \\
cluster & cluster (4 df) \\
$(1)$ & $(2)$ & $(3)$ \\
\hline
\end{tabular}

Panel A- Dependent variable: Probability to pass the high school exam

$\begin{array}{lccc}\beta_{03} \text { (effect in '03) } & 0.0044^{* *} & 0.0044 & 0.0044 \\ \beta_{04} \text { (effect in '04) } & (0.0020) & (0.0028) & (0.0031) \\ & 0.0106^{* * *} & 0.0106 * * * & 0.0106 * * * \\ \beta_{05} \text { (effect in '05) } & (0.0017) & (0.0018) & (0.0012) \\ & 0.0066^{* * *} & 0.0066^{* * *} & 0.0066 * * \\ \text { Observations } & (0.0015) & (0.0014) & (0.0014) \\ & 756,414 & 756,414 & 756,414\end{array}$

Panel B- Dependent variable: Average grade of high school graduates

\begin{tabular}{lrrr}
$\beta_{03}$ (effect in '03) & $0.0130 * * *$ & 0.0130 & 0.0130 \\
$\beta_{04}$ (effect in '04) & $(0.0047)$ & $(0.0061)$ & $(0.0062)$ \\
& 0.0060 & 0.0060 & 0.0060 \\
$\beta_{05}$ (effect in '05) & $(0.0050)$ & $(0.0063)$ & $(0.0066)$ \\
& 0.0087 & 0.0087 & 0.0087 \\
Observations & $(0.0049)$ & $(0.0087)$ & $(0.0065)$ \\
\hline
\end{tabular}

Source: Sekretariat der Ständigen Konferenz der Kultusminister der Länder in der Bundesrepublik Deutschland (2004-2007).

Notes: The dependent variable in Panel A is a binary variable that indicates whether the high school exam was passed (1) or not (0). The dependent variable in Panel B is the average high school grade (ranging from 1 for the best and 4 for the worst graduation results). The regressions described in equation (3) were run by Ordinary Least Squares. The standard errors are shown in parentheses. The standard errors in column 1 are clustered at the state-year level, in column 2 at the state level and in column 3 at the five region level.

** $p<0.05$

$* * * p<0.01$ 